\begin{tabular}{|l|l|l||}
\hline \multicolumn{2}{|c|}{ PublisherInfo } \\
\hline \hline PublisherName & $:$ & BioMed Central \\
\hline \hline PublisherLocation & $:$ & London \\
\hline \hline PublisherImprintName & $:$ & BioMed Central \\
\hline \hline
\end{tabular}

\title{
Error-prone polymerases make efficient immunity
}

\begin{tabular}{||l|l|l||}
\hline \multicolumn{2}{|c|}{ ArticleInfo } \\
\hline \hline ArticleID & $:$ & 4104 \\
\hline \hline ArticleDOI & $:$ & $10.1186 /$ gb-spotlight-20010601-01 \\
\hline \hline ArticleCitationID & $:$ & spotlight-20010601-01 \\
\hline \hline ArticleSequenceNumber & $:$ & 175 \\
\hline \hline ArticleCategory & $:$ & Research news \\
\hline \hline ArticleFirstPage & $:$ & 1 \\
\hline \hline ArticleLastPage & $:$ & 3 \\
\hline \hline & & RegistrationDate : 2001-06-01 \\
ArticleHistory & $:$ & OnlineDate \\
\hline \hline ArticleCopyright & $:$ & BioMed Central Ltd2001-06-01 \\
\hline \hline ArticleGrants & $:$ & \\
\hline \hline ArticleContext & $:$ & 130592211 \\
\hline \hline
\end{tabular}




\section{Tudor Toma}

Email: ttoma@mail.dntis.ro

When B cells encounter a pathogen for the second or third time, an enormous amplification of specificities and increase in antibody affinities is created by selectively mutating the antibody-encoding genes in a process known as somatic hypermutation. The mechanisms of this mutagenesis are unknown. Two papers in June Nature Immunology reveal some properties of the DNA polymerases involved in the mutation process.

Rogozin and colleagues from National Institute of Environmental Health Sciences, North Carolina, analysed mutational spectra of 15 immunoglobulin genes and found that consensus motifs RGYW and WA were universal descriptors of somatic hypermutations. Analysis of base-substitution hotspots in DNA polymerase error spectra showed that 33 of 36 hotspots in the human polymerase ? spectrum conformed to the WA consensus. This means that errors introduced by this enzyme during synthesis of the nontranscribed DNA strand in variable regions may contribute to strand-specific somatic hypermutagenesis of immunoglobulin genes at A-T base pairs (Nature Immunol 2001, 6:530-536).

In the second paper Zheng et al. from the National Institute of Aging, examined the frequency and pattern of substitutions in variable immunoglobulin genes (VH6) from the peripheral blood lymphocytes of three patients with xeroderma pigmentosum, whose DNA polymerase ? had genetic defects. They found a decrease in mutations at $\mathrm{A}$ and $\mathrm{T}$ and a concomitant rise in mutations at $\mathrm{G}$ and $\mathrm{C}$. It is probable that polymerase(s) other than polymerase ? may preferentially generate mutations opposite $\mathrm{G}$ and $\mathrm{C}$ (Nature Immunol 2001 6:537-541).

These findings further confuse the present understanding of the mechanism of somatic hypermutation and the challenge is now to define the order in which the error prone polymerases operate, says Ursula Storb, from the University of Chicago, in an accompanying News \& Views article.

\section{References}

1. National Institute of Environmental Health Sciences, [http://www.niehs.nih.gov/]

2. Rogozin IB, Pavlov YI, Bebenek K, Matsuda T, Kunkel TA: Somatic mutation hotspots correlate with DNA polymerase ? error spectrum. Nature Immunol 2001, 6:530-536., [http://immunol.nature.com]

3. National Institute of Aging, Baltimore, [http://www.nih.gov/nia/] 
4. Zeng X, Winter DB, Kasmer C, Kraemer KH, Lehmann AR, Gearhart PJ: DNA polymerase ? is an A-T mutator in somatic hypermutation of immunoglobulin variable genes. Nature Immunol 2001, 6:537-541., [http://immunol.nature.com]

5. University of Chicago, [http://www.uchicago.edu/]

6. Storb U. DNA polymerases in immunity: profiting from errors. Nature Immunol 2001, 6:484-485., [http://immunol.nature.com] 